\section{Entrevista com Clodoaldo Meneguello Cardoso}

Coordenador do Observatório de Direitos Humanos - OEDH-Unesp

por Mateus Beordo

Aracaju, abril de 2019

Pergunta - Seus estudos permeiam a filosofia, os direitos humanos e a ética. Como se entrelaçam na sociedade contemporânea estes três assuntos, visto que estes conceitos têm sido esvaziados e vulgarizados, pelo senso comum e pela mídia?

Clodoaldo Meneguello Cardoso (CMC) - Eu não diria categoricamente que os conceitos de filosofia, direitos humanos e ética estejam esvaziados e vulgarizados pelo senso comum e pela mídia. Tais conceitos estão na grande mídia, nas redes sociais e nas rodas de conversas a todo momento. Todavia é preciso ter claro que o senso comum é um tipo de conhecimento que tem finalidades mais práticas e a curto prazo; daí a visão mais superficial e até distorcida de certos assuntos. Por isso que, a partir deles, se buscam estudos acadêmicos mais aprofundados com a finalidade recolocá-los na vida prática com maior coerência e eficácia. Por sua vez, mídia possui um enorme pluralismo. Enquanto a grande mídia trata tais assuntos na ótica do consumo, a internet coloca ao alcance de todos, textos e vídeos sérios e cientificos sobre todos os assuntos. Cabe à universidade estimular, orientar e até coordenar a tarefa, transformá-los em material paradidático. Com esses propósitos realizo estudos, pesquisas e atividades no campo da ética e dos direitos humanos, tendo a filosofia como abrigo.

P - Dentre outros trabalhos, a partir de um acordo entre universidades da América do Sul, a Unesp fundou o Observatório de Educação em Direitos Humanos (ODEH), sob a sua liderança, com estudos importantes sobre direitos humanos, entre eles sobre diversidade e intolerância. Como o senhor abordou na última edição da Revista Interdisciplinar de
Direitos Humanos, os Direitos Humanos são conquistas históricas, processualmente construídas, necessitando a reflexão histórico-crítica cotidiana, pois "Os direitos humanos são humanos". Como vê os tempos de barbárie vividos na sociedade, onde algumas vertentes demonstram os direitos humanos como privilégios para alguns?

CMC - Realmente os direitos humanos são humanos e por isso uma construção histórica na luta de interesses contraditórios entre opressores e oprimidos. José Damião de Lima Trindade demonstra bem essa visão em "História social dos direitos humanos". A história humana não é única, linear e progressiva como pensavam vários pensadores do século XIX. Vemos avanços significativos na conquista de novos patamares de respeito à dignidade humana. Contudo, há retrocessos e barbáries, muitas vezes até concomitantes com os momentos de avanços do respeito aos direitos humanos em determinadas sociedades. Pensando globalmente para agir localmente, a luta pelos direitos humanos é constante. Quando uma pessoa sofre a violação de sua dignidade humana é uma violência contra toda a humanidade. A luta pelos direitos humanos estará sempre inconclusa. O horizonte sempre se afasta quando aproximamos dele.

P - Na edição 11, da Revista Interdisciplinar de Direitos Humanos, o senhor aborda que vivemos novos holocaustos em genocídios étnicos, religiosos e culturais. Quais as novas violências, os novos paradigmas e as possibilidades de emancipação? Como este ser social tem sido responsável pelos caminhos desta sociedade?

CMC - O conceito de emancipação é diverso em conteúdo e amplitude. Mesmo adotando o conceito de emancipação como superação do sofrimento injusto, causado por qualquer tipo de opressão, há vários os níveis de amplitude. No plano pessoal, pode-se compreender a emancipação como autonomia, não no sentido de liberdade de comportamento apenas, mas como consciência crítica do que se faz livremente adotando ou não às normas do grupo social.

Temos também a emancipação humana, no sentido marxista, que se configura como um processo de libertação da opressão na esfera do modo de produção capitalista e deve atingir uma socieda- 
de como um todo.

Enfim, podemos pensar a emancipação, numa esfera ainda mais ampla, partir da análise feita por Immanuel Wallerstein no livro: "O universalismo europeu: a retórica do poder". Para Wallerstein, vivemos a saturação do modelo civilizatório da modernidade européia. No seu DNA epistemológico e econômico contêm a dominação e a exclusão como estrutura fundante. Emancipação aqui é a construção de um novo paradigma de civilização que supere as verdades dogmáticas, o pensamento único, o consumismo, o individualismo e a exploração e exclusão do outro e da natureza. Este é o desafio no século XXI para uma nova "escola de sagres".

P - Um dos caminhos para a construção destes direitos humanos dobra-se ao ser ético e suas responsabilidades com 0 meio em que vive e com a dignidade humana. Quais os caminhos, avanços e retrocessos, deste projeto na sociedade?

CMC- AO caminho prioritário de defesa dos direitos humanos e de conquista de novos direitos é certamente o da ação coletiva organizada. Foi assim que ocorreu na história: os movimentos das mulheres, desde o final do século XIX, são um belo exemplo de luta pelo respeito à dignidade humana. Não há, contudo, evolução linear. Há uma multiplicidade de povos e culturas com avanços e recuos no respeito à dignidade humana de acordo com condições políticas, sociais, econômicas e até ambientais. Em países com boas condições econômicas, sociais e educacionais, como no Canadá, Noruega, Finlândia..., há maior possibilidade de avanços dos direitos individuais e sociais.

Por outro lado, vemos um flagelo imenso de populações inteiras de refugiados de guerras, de perseguições étnicas e de catástrofes ambientais, algumas delas provocadas pela ganância econômica, como ocorreram em campos de mineração no Brasil. Há também retrocessos no respeito aos direitos humanos, quando governos conservadores adotam políticas de restrição de direitos trabalhistas, de seguridade social pública e de educação. São situações de retrocesso no respeito à dignidade, pois as pessoas se sentem como individualmente descartáveis. Nesses casos o caminho é o da solidariedade e da resistência.
$P$ - A partir deste entendimento, o senhor apresenta, em entrevista concedida à Mayra Ferreira, da TV Unesp, em 07/04/2017 (Disponível em: <https:/www.youtube.com/watch?v=jQvFAecDm1w $>$ ) que, "Tudo que é humano está em processo contínuo de transformação no espaço e no tempo", e também aborda que há um afastamento entre a ética e a ciência e que os avanços tecnológicos e científicos não tem reduzido a barbárie. Qual o papel da universidade nesta sociedade e a participação social dos estudantes formados por ela?

CMC- Na Grécia antiga - de Sócrates, Platão e Aristóteles - o processo de conhecimento era também um processo de emancipação ético-política: a Paidéia. O projeto educacional desenvolvia a capacidade de descobrir e compreender da verdade 'cientifica' dos seres; e esta conquista somente poderia ser realizada por alguém que desenvolvesse as virtudes de relação equilibrada consigo mesmo e com o outro. Não é por outra razão que "verdade" e "bem" ou "ciência" $e$ "ética” são inseparáveis no pensamento grego. A ciência moderna, em sua infância, também teve sua promessa de felicidade com empiristas que fundavam uma ciência para minorar o sofrimento humano da condição efêmera da vida concreta e não mais a felicidade no plano metafísico, da ciência antiga. Como sabemos, o modo de produção capitalista inviabilizou divorciou a ciência da ética, colocando-a a serviço da acumulação do capital. Com isso, grande parcela da humanidade está sendo excluída das conquistas de ciência e tecnologias modernas.

A universidade pública, enquanto um locus especial de produção do saber científico, deve ter o compromisso social de resgatar a dimensão ética nas ciências, não apenas como comportamento pessoal de seus profissionais, mas como estrutura epistemológica e social. Este diálogo entre a ciência e a ética, hoje é feita pela educação em direitos humanos.

Neste sentido, o "Projeto Político Pedagógico" de cada curso e da universidade como um todo precisa explicitar este compromisso social em suas atividades de ensino, pesquisa e extensão envolvendo toda comunidade acadêmica.

P - Em entrevista que concedeu para JCNet, em 17/02/2013, à Ana Paula Pessoto (Disponível em: <https://www.jcnet.com.br/ 
Geral/2013/02/eu-sou-o-que-eu-sonho-ser. html $>$ ), o senhor diz "Eu sou o que eu sonho ser. Nós somos um pouco o que queremos ser amanhã. $O$ sonho também constrói. A vida é um processo de autoconhecimento". Como o senhor analisa a ética e os direitos humanos nas relações da sociedade e na construção da cidadania? Há possibilidades para o futuro?

CMC- Uma sociedade que tenha o sonho coletivo, a cultura de respeito à dignidade humana e de cuidado do meio ambiente é a grande utopia do século XXI, até porque dele depende a sobrevivência de todos. É preciso espalhar este sonho coletivo na educação formal e informal.

Somos a soma de nossas experiências, diz a psicanálise. O ser humano é um ser de projeto, diz o existencialismo. Portanto, manter viva a memória das dores dos tempos de barbárie e da tirania, para que nunca mais aconteça, e construir sonho coletivo para o futuro é nosso desafio. Qual sonho? O sonho de democracia social, com cidadania ativa e solidária, em que a liberdade e a igualdade seja um só guia

Recebido em: 02/04/2019

Publicado em: 13/07/2019 